\title{
Effects of Fenoprofen on the Labeling of Blood Constituents with Technetium-99m, the Morphology of Red Blood Cells and the Plasmid
}

\author{
Marcia de Oliveira Pereira ${ }^{1,2}$, Gabrielle de Souza Rocha ${ }^{1,2}$, Simone dos Santos Lombardi ${ }^{2}$, \\ Mauro Geller ${ }^{4}$, Mário José Pereira ${ }^{3}$, Sebastião David Santos-Filho ${ }^{2}$, Adenilson de Souza da \\ Fonseca $^{2,4, *}$ and Mario Bernardo-Filho ${ }^{2,5}$ \\ ${ }^{I}$ Centro de Ciências da Saúde; Universidade Federal do Rio Grande do Norte; Av. General Gustavo Cordeiro de \\ Farias, s/n; 59010180; Natal - RN - Brasil. ${ }^{2}$ Departamento de Biofísica e Biometria; Instituto de Biologia Roberto \\ Alcantara Gomes; Universidade do Estado do Rio de Janeiro; Rio de Janeiro - RJ - Brasil. ${ }^{3}$ Departamento de \\ Fisiologia; Av. 28 de setembro, 87; 20551030; Rio de Janeiro - RJ - Brasil. ${ }^{4}$ Centro de Ciências da Saúde; Centro \\ Universitário Serra dos Órgãos; Av. Alberto Torres, 111; 25964004; adenilso@uerj.br;Teresópolis - RJ - Brasil. \\ ${ }^{5}$ Instituto Nacional do Câncer; Praça Cruz Vermelha, 23; 20230-130; Rio de Janeiro - RJ - Brasil
}

\begin{abstract}
The aim of this work was to evaluate the effect of fenoprofen on the labeling of blood constituents with technetium$99 \mathrm{~m}$, on the morphology of red blood cells and on the plasmid DNA. Blood samples from Wistar rats were incubated with fenoprofen and the assay of labeling of blood constituents with technetium-99m $\left({ }^{99 m} \mathrm{Tc}\right)$ was performed. Blood cells, plasma, soluble and insoluble fractions of blood cells and plasma were separated. The radioactivity in each fraction was counted and percentage of incorporated radioactivity (\%ATI) was determined. Blood smears were prepared, fixed, stained and the qualitative and quantitative morphology of the red blood cells (RBC) was evaluated. Plasmid (pBSK) was incubated with fenoprofen with stannous chloride, and agarose gel electrophoresis procedure was carried out to evaluate genotoxic and the protection of this drug against stannous chloride effect on DNA. In conclusion, under the conditions used in this work, our data suggest that fenoprofen would not (i) affect the fixation of the ${ }^{99 m}$ Tc on the blood constituents, (ii) alter the RBC membrane and (iii) present genotoxic and redox effects.
\end{abstract}

Key words: technetium-99m, blood, morphology, plasmid, fenoprofen

\section{INTRODUCTION}

Nonsteroidal antiinflammatory drugs are used for treatment of rheumatic and other inflammatory, degenerative, and articulate diseases (Insel, 2001). The action mechanism of these drugs results from the inhibition of cyclooxygenase activity, with a consequent reduction of the synthesis of prostaglandin, one of the main mediators of the inflammatory process (Poggi et al., 2006). Fenoprofen is a nonselective cyclooxygenase inhibitor commonly used for the treatment of acute and chronic pain (Insel, 2001).

\footnotetext{
* Author for correspondence
} 
In vitro red blood cells (RBC) labeled with technetium-99m $\left({ }^{99 \mathrm{~m}} \mathrm{Tc}\right)$ has been proposed as an assay to assess biological effects of natural and synthetic drugs (Fonseca et al., 2007; Benarroz et al., 2008). Morphogical analysis of RBC has been utilized as another method to evaluate effects of drugs (Frydman et al., 2008). Electrophoretic profile of bacterial plasmids has also been used as a reliable assay to evaluate genotoxic effect of drugs (Ferreira-Machado et al., 2004).

The aim of this work was to evaluate the effect of fenoprofen on the labeling of blood constituents with ${ }^{99 \mathrm{~m}} \mathrm{Tc}$, on the morphology of $\mathrm{RBC}$ and on the plasmid DNA.

\section{MATERIALS AND METHODS}

\section{Drugs}

Fenoprofen used in this study was purchased from Biolab Sanus Farmacêutica Ltda (São Paulo, Brazil, lot 601034) and stannous chloride $\left(\mathrm{SnCl}_{2}\right)$ was purchased from Sigma Chemicals $\mathrm{Co}$ ( $\mathrm{St}$ Louis, USA).

\section{Animals}

Adult male Wistar rats (3-4 months, 250-300 g) were maintained in a controlled environment: normal light/dark cycle conditions (12-h light/12-h dark; lights on at $6 \mathrm{am}$ ), free access to water and food and room temperature was kept at $25 \pm 2{ }^{\circ} \mathrm{C}$. Experimental protocols were approved by the Ethical Committee of the Instituto de Biologia Roberto Alcantara Gomes, Universidade do Estado do Rio de Janeiro (protocol number CEA/203/2007).

\section{In vitro radiolabeling of blood constituents}

Samples of whole blood ( $\mathrm{n}=7$, for each fenoprofen concentration) were incubated with this drug at different concentrations $(0.0,0.1,1.0,10,100$, $1000 \mu \mathrm{g} / \mathrm{mL} ; 1$ hour$)$. After that, $\mathrm{SnCl}_{2}(1.2$ $\mu \mathrm{g} / \mathrm{mL}, 1$ hour) was added and, in sequence, ${ }^{99 \mathrm{~m}} \mathrm{Tc}$ (3.7 $\mathrm{MBq}, 10$ minutes) as sodium pertechnetate $\left(\mathrm{Na}^{99 \mathrm{~m}} \mathrm{TcO}_{4}\right)$, recently milked from a ${ }^{99} \mathrm{Mo} /{ }^{99 \mathrm{~m}} \mathrm{Tc}$ generator (Instituto de Pesquisas Energéticas e Nucleares, Comissão Nacional de Energia Nuclear, São Paulo, Brazil). These samples were centrifuged (1500 rpm, 5 minutes) and plasma (P) and blood cells (BC) were separated. Aliquots of $\mathrm{P}$ and $\mathrm{BC}$ were also precipitated with trichloroacetic acid (5\%) and soluble (SF) and insoluble (IF) fractions were obtained. The radioactivity (\% ATI) in P, BC, IF-P, SF-P, IF-BC and SF-BC was determined in a well gamma counter (Packard, model C5002, Illinois, USA). The \%ATI was calculated as described previously (Bernardo-Filho et al., 1983).

\section{Morphological evaluation}

Smears were prepared from blood samples incubated with fenoprofen at different concentration $(0.0,0.1,1.0,10,100,1000 \mu \mathrm{g} / \mathrm{mL}$; 5 slides for each concentration) and stained by May-Grünwald-Giemsa (Barcia, 2007). The slices were analyzed by optical microscopy and for morphometric measurements a total of five fields per each slide were evaluated. A spherical shape and normal size distribution were assumed to RBC on control samples. Area and perimeter of RBC were measured (Software image pro plus, media Cibernetics, USA) and perimeter/area ratio was calculated.

\section{Plasmid DNA}

Plasmid (pBSK) was obtained by alkaline cell lysis method (Sambrook et al,. 1989) from Escherichia coli DH5aF'Iq (rec-) strain hosting this plasmid.

\section{Plasmid treatment with fenoprofen}

Plasmids were incubated with fenoprofen at different concentrations $(3.0,30,300 \mu \mathrm{g} / \mathrm{mL})$. To assess the action of fenoprofen on effects of $\mathrm{SnCl}_{2}$, plasmids were incubated with fenoprofen, at the same concentrations, in the presence of $\mathrm{SnCl}_{2}(200$ $\mu \mathrm{g} / \mathrm{mL}$ ). Plasmid incubated only with $\mathrm{SnCl}_{2}$ was used as positive control and, as negative control, plasmid incubated at $10 \mathrm{mM}$ Tris buffer (vehicle, $\mathrm{pH}$ 7.4). The incubations were carried out at room temperature for 40 minutes. After that, each sample was mixed with loading buffer $(0.25 \%$ xylene cyanol, $0.25 \%$ bromophenol blue and glycerol in water) and applied in $0.8 \%$ agarose horizontal gel electrophoresis chamber in Trisacetate-EDTA buffer $(\mathrm{pH} 8.0,7 \mathrm{~V} / \mathrm{cm})$. The gel was stained with ethidium bromide $(0.5 \mu \mathrm{g} / \mathrm{mL})$ and the DNA bands were visualized by fluorescence under an ultraviolet transilumination system. The assay was repeated at least four times, the results were digitalized (Kodak Digital Science 1d, EDAS 120) and the bands semiquantified using the computer program Image $\mathrm{J}$ for Windows. 


\section{Statistical analysis}

Data are reported as (means $\pm \mathrm{SD}$ ) of the \%ATI, the perimeter/area ratio and the percentual of plasmid forms. The One-way analysis of varianceANOVA test was performed to verify possible statistical differences $p<0.05$ as less significant level.

\section{RESULTS}

Table 1 presents the effects of fenoprofen on the radioactivity distribution between cellular and plasma compartments. This data indicates no alteration $(p<0.05)$ of ${ }^{99 \mathrm{~m}} \mathrm{Tc}$ distribution in these compartments.

Table 1 - Effect of fenoprofen on the radioactivity distribution on the cells and plasma compartments labeled with ${ }^{99 \mathrm{~m}} \mathrm{Tc}$.

\begin{tabular}{ccc}
\hline $\begin{array}{c}\text { Fenoprofen } \\
(\mu \mathbf{g} / \mathbf{m L})\end{array}$ & $\mathbf{P}$ & \%ATI \\
\cline { 2 - 3 } 0.0 & $2.82 \pm 0.54$ & $\mathbf{B C}$ \\
0.1 & $1.99 \pm 0.59$ & $97.18 \pm 0.54$ \\
1.0 & $2.49 \pm 1.21$ & $98.01 \pm 0.59$ \\
10 & $1.92 \pm 0.55$ & $97.51 \pm 1.21$ \\
100 & $3.95 \pm 1.60$ & $98.08 \pm 0.55$ \\
1000 & $4.39 \pm 4.02$ & $96.05 \pm 1.60$ \\
& & $95.61 \pm 4.02$ \\
\hline
\end{tabular}

Table 2 presents the effect of fenoprofen on the fixation of ${ }^{99 \mathrm{~m}} \mathrm{Tc}$ on insoluble and soluble fractions plasma proteins. This data indicates that the fenoprofen was not capable to interfere on the fixation of the radioactivity on the insoluble and soluble fractions of plasma.
No alteration on fixation of radioactivity on proteins of blood cells from blood samples incubated with fenoprofen (Table 3) was found.

Table 2 - Effect of fenoprofen on the fixation of ${ }^{99 \mathrm{~m}} \mathrm{Tc}$ on soluble and insoluble fractions of plasma.

\begin{tabular}{ccc}
\hline $\begin{array}{c}\text { Fenoprofen } \\
(\boldsymbol{\mu g} / \mathbf{m L})\end{array}$ & \multicolumn{2}{c}{ \%ATI } \\
\cline { 2 - 3 } SF-P & IF-P \\
0.0 & $24.19 \pm 2.67$ & $75.81 \pm 2.67$ \\
1.0 & $31.90 \pm 3.87$ & $68.10 \pm 3.87$ \\
10 & $26.00 \pm 4.00$ & $74.00 \pm 4.00$ \\
100 & $25.99 \pm 6.18$ & $74.01 \pm 6.18$ \\
1000 & $25.31 \pm 5.55$ & $74.69 \pm 5.55$ \\
& $25.87 \pm 7.78$ & $74.13 \pm 7.78$ \\
\hline
\end{tabular}

Table 3 - Effect of fenoprofen on the fixation of ${ }^{99 \mathrm{~m}} \mathrm{Tc}$ on soluble and insoluble fraction of blood cells.

\begin{tabular}{ccc}
\hline $\begin{array}{c}\text { Fenoprofen } \\
(\boldsymbol{\mu g} / \mathbf{m L})\end{array}$ & \multicolumn{3}{c}{ \%ATI } \\
\cline { 2 - 3 } SF-BC & IF-BC \\
\hline 0.0 & $19.56 \pm 2.77$ & $80.44 \pm 2.77$ \\
1.0 & $19.81 \pm 2.76$ & $80.19 \pm 2.76$ \\
10 & $18.34 \pm 3.96$ & $81.66 \pm 3.96$ \\
100 & $18.84 \pm 2.30$ & $81.16 \pm 2.30$ \\
1000 & $20.63 \pm 2.66$ & $79.37 \pm 2.66$ \\
& $18.58 \pm 3.05$ & $81.42 \pm 3.05$ \\
\hline
\end{tabular}


Photomicrographs of $\mathrm{RBC}$ from blood incubated Table 4 presents the perimeter/area ratio of RBC with $0.9 \% \mathrm{NaCl}$ or fenoprofen $(1000 \mu \mathrm{g} / \mathrm{mL})$ from blood samples incubated with fenoprofen. under optical microscopy is shown in the figures 1 The results indicate that the perimeter/area ratio of and 2. Qualitative evaluation of these figures RBC was not significantly $(p>0.05)$ altered by indicates no alterations on the shape of the RBC fenoprofen at the concentrations used. incubated with fenoprofen.

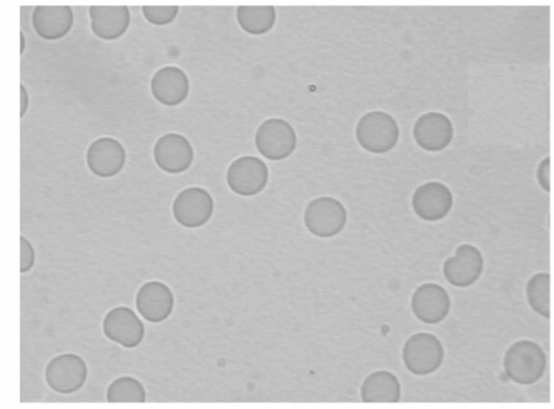

(a)

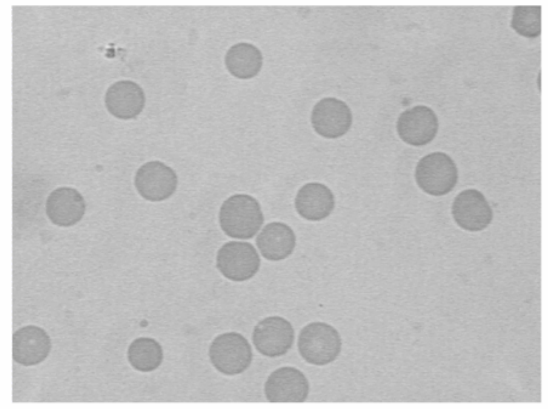

(b)

Figure 1 - Photomicrography of blood smear from blood incubated with $0.9 \% \mathrm{NaCl}$ (control) (a) and Photomicrography of blood smear from blood incubated with fenoprofen (1000 $\mu \mathrm{g} / \mathrm{mL})(\mathrm{b})$.

Table 4 - Effect of fenoprofen the perimeter/area ratio of RBC.

\begin{tabular}{cc}
$\begin{array}{c}\text { Fenoprofen } \\
(\mu \mathrm{g} / \mathbf{m L})\end{array}$ & $\begin{array}{c}\text { Perimeter/área ratio } \\
(\mathbf{1} / \mathbf{\mu m})\end{array}$ \\
0.0 & $0.62 \pm 0.01$ \\
0.1 & $0.64 \pm 0.01$ \\
1.0 & $0.65 \pm 0.02$ \\
10 & $0.66 \pm 0.02$ \\
100 & $0.64 \pm 0.01$ \\
1000 & $0.63 \pm 0.01$ \\
\hline
\end{tabular}

The Figure 2 shows the photograph of agarose gel that the effect of $\mathrm{SnCl}_{2}$ (lane 2) is not altered by electrophoresis of pBSK plasmid treated with fenoprofen at concentrations used (lanes 6,7 and fenoprofen in presence and absence of $\mathrm{SnCl}_{2}$. This 8). These results were confirmed by figure indicates that fenoprofen is not capable to semiquantitative analyses of the percentages of induce alterations on the electrophoretic profile of supercoiled (SC) and open circle (OC) plasmid plasmids (lanes 3, 4 and 5) when compared with forms (Fig. 3) indicating no alteration on the negative control (lane 1). Also, figure 2 indicates electrophoretic profile. 


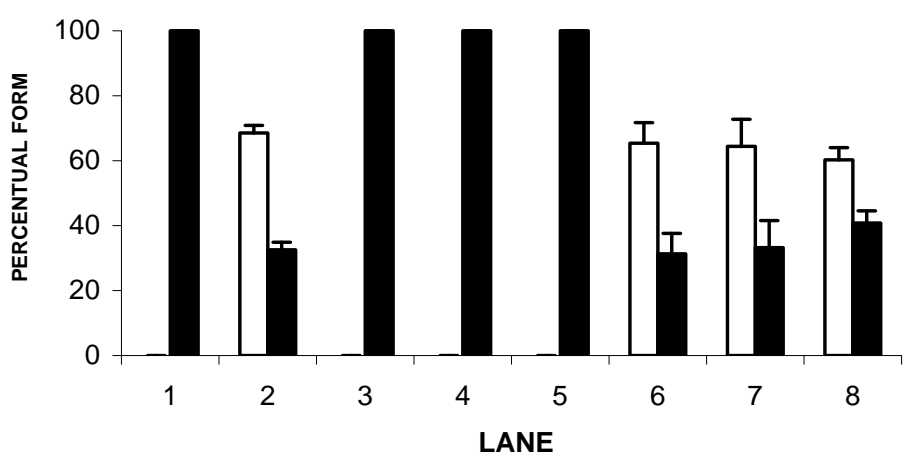

(a)

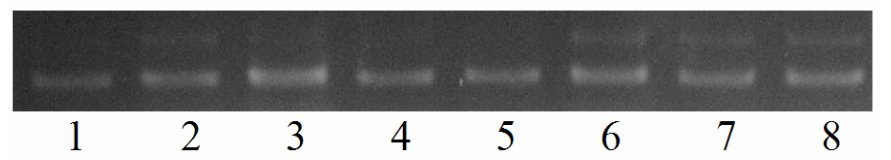

(b)

Figure 2 - Percentage of topological forms (a) and photograph (b) of agarose gel electrophoresis of plasmid pBSK treated with fenoprofen in presence and absence of $\mathrm{SnCl}_{2}$. Lanes: (1) $\mathrm{pBSK}+$ buffer (negative control); (2) $\mathrm{pBSK}+\mathrm{SnCl}_{2}$ (positive control); (3) $\mathrm{pBSK}+$ fenoprofen $(300 \mu \mathrm{g} / \mathrm{mL})$; (4) pBSK + fenoprofen $(30 \mu \mathrm{g} / \mathrm{mL}) ;(5) \mathrm{pBSK}+$ fenoprofen $(0.3 \mu \mathrm{g} / \mathrm{mL}) ;(6) \mathrm{pBSK}+$ fenoprofen $(300 \mu \mathrm{g} / \mathrm{mL})+\mathrm{SnCl}_{2} ;(7) \mathrm{pBSK}+$ fenoprofen $(30$ $\mu \mathrm{g} / \mathrm{mL})+\mathrm{SnCl}_{2} ;(8) \mathrm{pBSK}+$ fenoprofen $(3.0 \mu \mathrm{g} / \mathrm{mL})+\mathrm{SnCl}_{2}$. (घ) OC (open circle); (口) SC (supercoiled).

\section{DISCUSSION}

Blood constituents labeled with ${ }^{99 \mathrm{~m}} \mathrm{Tc}$ have been used in several clinical examinations (Saha, 2004) and also as an experimental assay to verify the effect of drugs on radiopharmaceuticals (Fonseca et al., 2007). This experimental model has permitted the obtaining of relevant information about properties of various chemical compounds (synthetic and natural) (Benarroz et al., 2008). The data obtained in this work indicates that there was no alteration on the labeling of the blood constituents with ${ }^{99 \mathrm{~m}} \mathrm{Tc}$ when the blood was incubated with fenoprofen (tables 1, 2 and 3). Despite the absence of effects of the fenoprofen on radiolabeling of blood constituents, it has described drug-related immune hemolytic anemia after use of fenoprofen in human beings (Shirey et al., 1988). Other data has indicated that fenoprofen is almost completely bond to plasma proteins (Insel, 2001).
Morphological analysis has been used to demonstrate effects of salicylic acid derivatives on membrane of $\mathrm{RBC}$ ( $\mathrm{Li}$ et al., 1999). On the other hand, our data indicates that fenoprofen would not alter the morphology of RBC (Fig. 1 and table 4). As morphological analysis of RBC has been used as complementary technique, these results could confirm the data obtained with fenoprofen on the labeling of blood constituents with ${ }^{99 \mathrm{~m}} \mathrm{Tc}$.

The genotoxic effect of stannous chloride on DNA has been demonstrated by different experimental models and the mechanism action has been so far related to free radical generation (Melo et al. 2001, Dantas et al. 2002). In fact, the presence of free radicals scavengers could reduce the changes of electrophoretic profile of plasmid DNA induced by stannous chloride decreasing the DNA strand breaks (Dantas et al. 1999, de Mattos et al., 2000). Fenoprofen has been suggested to be scavenger of free radicals (Costa, et al., 2006). However, at 
conditions used in this work, fenoprofen did not seem to protect plasmid DNA against the effects of stannous chloride. In addition, fenoprofen could not present genotoxic effect because no alteration on the electrophoretic profile of plasmids was observed (Fig. 2).

In conclusion, under the conditions used in this work, our data suggest that fenoprofen would not (i) affect the fixation of the ${ }^{99 \mathrm{~m}} \mathrm{Tc}$ on the blood constituents, (ii) alter the RBC membrane and (iii) present genotoxic and redox effects.

\section{ACKNOWLEDGEMENTS}

This study was supported by grants and financial support from CAPES, CNPq and FAPERJ.

\section{RESUMO}

O objetivo deste trabalho foi avaliar o efeito do fenoprofeno na marcação de constuintes sanguíneos com tecnécio-99m $\left({ }^{99 m} \mathrm{Tc}\right)$, na morfologia de hemácias e no DNA plasmidial. Amostras de sangue de ratos Wistar foram incubadas com fenoprofeno e a marcação de constituintes sangüíneos com ${ }^{99 \mathrm{~m}} \mathrm{Tc}$ foi realizada. Células sanguiíneas (CS) e plasma (P) foram isolados. Alíquotas de CS e P foram precipitadas, frações insolúvel e solúvel foram separadas. A radioatividade em cada fração foi contada e o percentual de radioatividade incorporada (\%ATI), determinada. Distensões sangüíneas foram preparadas, fixadas, coradas e análise morfológica, qualitativa e quantitativa, de hemácias foi realizada sob microscopia óptica. Plasmídios pBSK foram incubados com fenoprofeno na presença e ausência de cloreto estanoso, e o procedimento de eletroforese em gel de agarose realizado para avaliar o efeito genotóxico deste fármaco e seu efeito sobre a ação do cloreto estanoso no DNA. Os resultados obtidos sugerem que, nas condições utilizadas nesse estudo, o fenoprofeno não poderia: (i) afetar a fixação do ${ }^{99 \mathrm{~m}} \mathrm{Tc}$ nos constituintes sanguíneos, (ii) alterar a membrana de hemácias e (iii) apresentar efeitos genotóxicos e redox.

\section{REFERENCES}

Benarroz, M. O.; Fonseca, A. S.; Rocha, G. S.; Frydman, J. N.; Rocha, V. C.; Pereira, M. O.; Bernardo-Filho, M. (2008), Cinnamomum zeylanicum extract on the radiolabelling of blood constituents and the morphometry of red blood cells: In vitro assay. Appl Radiat Isot., 66, 139-146.

Barcia, J. J. (2007), The Giemsa stain: its history and applications. Int. J. Surg. Pathol., 15, 292-296.

Bernardo-Filho, M.; Santos-Filho, S. D.; Moura, E. G.; Maiworm, A. I.; Orlando, M. M. C.; Penas, M. E.; Cardoso, V. N.; Bernardo, L. C.; Brito, L. C. (2005), Drug Interaction with Radiopharmaceuticals: a Review. Braz. Arch. Biol. Technol., 48, 13-28.

Bernardo-Filho, M.; Moura, I. N. S.; Boasquevisque,

M. (1983), 99m technetium - labeled red blood "in vitro". Arq. Biol. Technol., 4, 455-461.

Costa, D.; Moutinho, L.; Lima J. L. F.; Fernandes, E. (2006), Antioxidant activity and inhibithion of human neutrophil oxidative burst mediated by arylpropionic acid non-steroidal anti-inflamatory drugs. Phamaceut. Soc. Japan, 29, 1659-1670.

Dantas, F. J. S.; De Mattos, J. C. P.; Viana, M. E.; Lage, C. A. S.; Cabral-Neto, J. B.; Leitão, A. C.; Bernardo-Filho, M.; Bezerra; R. J. A. C.; Carvalho; J. J.; Caldeira-de-Araújo, A. (2002), Genotoxic effects of stannous chloride $\left(\mathrm{SnCl}_{2}\right)$ in $\mathrm{K} 562$ cell line. Food Chem Toxicol., 40, 1493-1498.

Dantas, J. S. F.; Morais, O.; Mattos, C. P. J.; Bezerra, J. A. C. R.; Carvalho, F. E.; Bernardo-Filho, M.; Araújo, C. A. (1999), Stannous chloride mediates single strand breaks in plasmid DNA through reactive oxygen species formation. Toxicol Lett., 110, 129136.

Ferreira-Machado, S. C.; Rodrigues, M. P.; Nunes, A. P.; Dantas, F. J.; De Mattos, J. C.; Silva, C. R.; Moura, E. G.; Bezerra, R. J.; Caldeira-de-Araujo, A. (2004), Genotoxic potentiality of aqueous extract prepared from Chrysobalanus icaco L. leaves. Toxicol Lett., 151, 481-488.

Fonseca, A. S.; Frydman, J. N.; Rocha, V. C.; Bernardo-Filho, M. (2007), Acetylsalicylic acid decreases the labeling of blood constituents with technetium-99M. Acta Biol Hung., 2, 187-198.

Freitas, R. S.; Moreno, S. R. F.; Lima-Filho, G. L.; Fonseca, A. S.; Bernardo-Filho, M. (2007), Effect of a comercial extract of Paulinia cupana (guaraná) on the biding of $99 \mathrm{mTc}$-DMSA on blood constituents: An in vivo study. Appl Radiat Isot., 65, 528-533.

Hladik III, W. B.; Saha, G. B.; Study, K. T. (1987), Essentials of nuclear medicine science. Williams and Wilkins, Baltimore, London. 
Insel, P. A. (2001), Analgesic-antipiryretic and antiinflamatory agentes and drugs employed in the treatment of gout. In: Harman, J.G., Limbird, L. E., Gilman, A.G. (eds) The Pharmacological Baisis of Therapeutics. 10th McGraw/Hill, New York; pp. 617-657.

Li, A.; Seipelt, H.; Muller, C.; Artmann, M.; (1999), Effects of salicylic acid derivatives on red blood cell membranes. Pharmacol Toxicol., 85, 206-211.

Melo, S. F.; Soares, S. F.; da Costa, R. F.; da Silva, C. R.; de Oliveira, M. B.; Bezerra, R. J.; Caldeira-deAraujo, A.; Bernardo-Filho, M. (2001), Effect of the Cymbopogon citratus, Maytenus ilicifolia and Baccharis genistelloides extracts against the stannous chloride oxidative damage in Escherichia coli. Mutat Res., 496, 33-38.

Moreno, S. R. F.; Rocha, E. K.; Pereira, M.; MandarimLacerda, C.; Freitas, R. S.; Nascimento, A. L. R. Carvalho, J. J.; Lima-Filho, G. L.; Diré, G.; Lima, E. A. C.; Bernardo-Filho, M. (2004), Ginkgo biloba extract: experimental model to evaluate its action on the labeling of blood elements with Technetium-99m and on the morphometry of red blood cells. Pak J Nutr., 3, 68-71.

Oliveira, J. F. F.; Brito, L. C.; Frydman, J. N. D.; Santos-Filho, S. D.; Bernardo-Filho, M. (2005), An aqueous extract of Pfaffia sp. does not alter the labeling of blood constituents with technetium-99m and the morphology of the red blood cells. Braz J Pharmacol., 15, 126-132.
Poggi, J. C.; Barissa, G. R.; Donadi, E. A.; Foss, M. C. Cunha, F. Q.; Lanchote, V. L.; Reis, M. L. (2006), Pharmacodynamics, Chiral Pharmacokinetics, and Pharmacokinetic-Pharmacodynamic Modeling of Fenoprofen in Patients With Diabetes Mellitus. J Clin Pharmacol., 46; 1328.

Santos-Filho, S. D.; Bernardo-Filho, M. (2005), Effect of Hypericum perforatum extract in vitro labeling of blood elements with technetium-99m and on biovailability of sodium pertechentate in Wistar rats. Acta Cir Bras., 1, 76-80.

Saha, G. B. (2004), Fundamentals in Nuclear Pharmacy. Springer-Verlag, New York.

Sambrook, J.; Fritsch, E. F.; Maniatis, T. (1989), Molecular cloning: a laboratorial manual. Cold Spring Harbor Laboratory Press, New York.

Shirey, R.S.;Morton; S. J.; Lawton, K. B., Lowell, C.;Kickler, T. S.; Ness, P. M. (1988), Fenoprofeninduced immune hemolysis. Difficulties indiagnosis and complications in compatibility testing. Am J Clin Pathol., Mar., 89, 410-4.
Received: August 28, 2008; Revised: September 16, 2008; Accepted: September 18, 2008. 